Ambiances

anbiances Environnement sensible, architecture et espace urbain

$2 \mid 2016$

Ambiance et histoire de l'architecture : l'expérience et l'imaginaire sensibles de l'environnement construit

\title{
Building Artificial Climates. Thermal control and comfort in Modern Architecture (1930-1960)
}

La fabrique des climats artificiels. Régulation thermique et confort dans

l'architecture moderne (1930-1960)

Ignacio Requena-Ruiz

(2) OpenEdition

Journals

Electronic version

URL: http://journals.openedition.org/ambiances/801

DOI: 10.4000/ambiances.801

ISSN: 2266-839X

Publisher:

Direction Générale des Patrimoines - DAPA - MCC, UMR 1563 - Ambiances Architectures Urbanités (AAU)

Electronic reference

Ignacio Requena-Ruiz, « Building Artificial Climates. Thermal control and comfort in Modern

Architecture (1930-1960)», Ambiances [Online], 2 | 2016, Online since 07 November 2016, connection on 19 April 2019. URL : http://journals.openedition.org/ambiances/801 ; DOI : 10.4000/

ambiances.801

This text was automatically generated on 19 April 2019

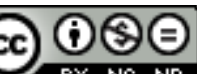

Ambiances is licensed under a Creative Commons Attribution-NonCommercial-NoDerivatives 4.0

International License. 


\title{
Building Artificial Climates. Thermal control and comfort in Modern Architecture (1930-1960)
}

\author{
La fabrique des climats artificiels. Régulation thermique et confort dans \\ l'architecture moderne (1930-1960)
}

Ignacio Requena-Ruiz

1 Notions such as temperature, humidity or comfort, being intimately linked with energy efficiency and well-being, are nowadays integrated into architectural discourse from different points of view. These perceptual and physical qualities are recognized as particularly important in the everyday experience of architecture and, furthermore, they connect the representations of indoor spaces to outdoors (Heschong, 1979; Pallasmaa, 2011; Chappells and Shove, 2004). Depending on our physiological and psychological reactions to the thermal characteristics of a space, we perceive indoors as warm, cool, humid, airy, radiant, cosy and so on. Thermal characteristics therefore intermingle both tangible and immaterial dimensions of the built environment - in other words, its atmosphere (i.e. Böhme, 1993; Ingold, 2000; Thibaud, 2014).

From the late nineteenth century onwards, the hygienist movement refocused the attention of Hippocratic medicine on the human milieu in the light of modern science. The discovery of microbes pointed towards the purity of the environment as a sociotechnical solution to the increasing health problems in modern society - i.e. rickets and tuberculosis. To this end, the scientific community highlighted two main environmental issues. In the first place, there was solar accessibility and shadow casting, based on the bactericidal power of sunlight and its representation of purity (Carter, 2007; Ory, 2008). A variety of contemporary studies focus on sunlight as an agent of cultural, medical and technological changes throughout the twentieth century (Campbell, 2005; Hobday, 2006; Siret, 2013). In the second place, there was clean air and open air, based on concerns about $\mathrm{CO}_{2}$ concentration and odours that dated back to the late eighteenth century. 
Historical research from different approaches reveals that their social representations conditioned indoor architecture (Corbin, 1982; Overy, 2007; Simonnet, 2014).

Different studies on the history of science and techniques have shown how twentiethcentury innovations in thermal conditioning techniques led to new physical and sensory approaches to architectural spaces (Cooper, 1998; Gallo, 2008; Barber, 2010; Marino, 2014). This contributed to the modernist ambition to create healthier environments for future society. In this sense, Ackermann's cultural history of air conditioning reveals the influence of these techniques not only in the world of experts, but also in popular material culture (Ackermann, 2002). Similarly, the alliance of technique with medicine (Turda, 2010) and design (Cogdell, 2004) echoed the modernist social and political programme. As Turda states, such a discourse cannot be detached from the emerging notions of social hygiene and eugenics. Furthermore, the close relationship between environmental control and human behaviour and efficiency is related to Foucault's politics of control and bio-political power (Foucault, 2004). Following this view, Sloterdijk (2006) uses the notion of "air design" to explain how modern technologies of environmental control influence a broad range of fields - i.e. politics, psychology, physiology, the built environment.

Although a number of historians have dealt with this topic in a fragmented manner, little research has studied its relationship to architecture from a broader perspective: that is to say, considering its historical ubiquity within modern cultures, techniques or sensory perceptions not as an "exterior relation between things, but the sign of relationship" (Foucault, 1966, p. 20). The contribution of architecture and architects to the materialization of thermal atmospheres, or conversely, the potential implications of ambient parameters in architectural design and thought, remain little studied. Indeed, some authors (Banham, 1969; Anker, 2010) have criticized the fact that architects and architectural historians had long neglected the intangible dimensions of architecture and their overlapping with building services - heating, cooling or ventilation. As a result, thermal modernity emerges as a "new space of critical debate" in the history of architecture (Chang and Winter, 2015). How did this climatic dimension of indoor atmospheres emerge in Modernism? What were the climatic properties expected for the atmospheres for modern ways of life? Did cultural, sensory or political facets of climate become agents of architectural transformation? How did architects and engineers translate this preoccupation at the interface between building physics, sensory perception and architectural gesture?

In order to answer these questions, the first part of this article focuses on the different understandings of the notion of climate during the central decades of the twentieth century. Our aim is not to provide an exhaustive citation of all the specific literature on climatic studies. Indeed, our objective is to explain the multidisciplinary panorama of climate and indoor atmospheres over the period considered: from macro- to picoclimates, from natural to artificial climates, from outdoor to indoor climates. In the second part, we look at the key moments and projects arising from the collaboration between an architect and an engineer that were critical in the understanding of climates, bodies and architecture: Le Corbusier (1887-1965) and André Missenard (1901-1989). These sections are not an exhaustive topical analysis of Le Corbusier's work either, but an exploration of the interferences between modern climatic discourse and his architecture. 


\section{The climate studies and the manufacturing of climates}

6 In the early twentieth century, the conjunction of disparate understandings of the notion of climate brought about an enlargement of the representations of the notion itself and the implications of the climate discourse. This emergence of climate studies can be explained, on the one hand, by the constitution of a cross-curricular field that established causal links between climates and hygiene, culture, biology or economy. On the other hand, there was the emergence of a variety of thermal control technologies, which continued innovative work on heating, ventilation and greenhouses construction which was carried out in the previous century.

7 Focusing on the widening of climate discourse, Jankovic (2010) looks at the eighteenthcentury European naturalists who developed new doctrines on climate interactions with human physiology, health and everyday life. These works exposed a variety of links between "climate [and] social welfare and gave an impetus to medical topography, travel health issues, altitude physiology, eudiometry and ventilation" (Fleming and Jankovic, 2011). Furthermore, European colonialism understood climate in terms of health and coherence of global empires (Richards, 1993). Architecture was significant for that purpose (van der Plaat, 2014). In the interwar period, climate studies oriented on war analysed climatology as well as human and machine reactions to climate as a geopolitical matter. The development of new organizations - i.e. the US Army Air Corps Weather Service (1937) or the United Nations World Meteorological Organization (1951) - and research centres - i.e. the Harvard Fatigue Laboratory (1927-1947) - provides evidence of this awareness.

Attempts to theorize the relationship of both society and individuals with climate were carried by the "climatic determinism" at the beginning of the twentieth century. Geographers like Ellsworth Huntington (1876-1947) or Albrecht Penck (1858-1945) popularized a socio-climatic theory in Europe and North America. Their thesis argued for the determining role of climate in civilization, intellectual vigour or moral virtue (Hulme, 2011). Consequently, climatic therapies were tainted by eugenics and their relation to totalitarian ideologies: the Soviet Union, Fascist Italy or the Wohnkultur of Nazi Germany (Overy, 2007). At the same time, several experiments explored the role of climate in disease and in achieving a positive state of health. Examples of these are the open-air school movement (Châtelet, 2011), the heliotherapy and actinotherapy methods (Carter, 2012; Ory, 2006) or the British Peckham Experiment (Barlow, 2012). With the aim of strengthening the human body, tuning it like an engine and making it healthy, efficient and vigorous, the culture of sunshine and open air played a central role. In short, this period saw the emergence of a vast doctrine of climate that interacted with a variety of other domains; therefore, as Fleming and Jankovic (2011) state, climate discourse cannot be reduced to the aspect of climatology. Particularly in architecture, the intricate relationship between the notions of milieu, hygiene and climate evolved during the early twentieth century with the growth of urban climatology and research in industrial hygiene and residential quality of life.

9 As thermal conditioning techniques come into focus, the climatic concern focusing on health and society reveals a complementary approach. The history of science and techniques explains how the first buildings designed as thermal machines themselves 
were agricultural greenhouses (Fernandez-Galiano, 2000). Against this background, the term 'artificial climate' emerged as an attempt to reproduce climatic conditions of other latitudes for plant growing. Yet the potential of such procedures led to theories about using greenhouses for housing (Loudon, 1817) or public demonstrative works such as Joseph Paxton's Crystal Palace (1851).

"When subsequent improvements in communicating heat, and in ventilation, shall have rendered the artificial climates produced, equal or superior to those which they imitate, then will such an appendage to a family seat be not less useful in a medical point of view, than elegant and luxurious as a lounge for exercise or entertainment in inclement weather" (Loudon, 1817, p. 49)

Technical advances in ventilation, air purification and hygrothermal regulation made real the possibility of controlling spatially confined atmospheres. A variety of inventions shows this interest: for example, the "Climatogène" (1901) of the French engineer Bontemps, the first "air conditioning unit" (1902) of the American industrialist Willis Carrier, or the "appareil pour laver l'air" (air washing machine) (1910) of the French physiologist Charles Richet. In Carrier's words, such devices sought to "control [of] desired atmospheric conditions... with respect to moisture, temperature and purity" (Carrier and Busey, 1911). The concerns with sunshine and openness of the social-democratic life of the 1920 s and the 1930s opened up a new dimension through the potentialities of air conditioning techniques.

11 This shift towards a "mechanistic hygienism" was accompanied by the emergence of mass media (Colomina, 1994). As in other areas, the interference between science and culture conditioned everyday habits in relation to thermal atmospheres. Studies and innovations in thermal atmospheres were not just transferred to society; they also triggered a change in the cultural approach, as Ackermann (2002) explains. For instance, introducing air conditioning systems in cinemas, theatres, commercial centres or offices modified both architectural typologies and the population's perception of their thermal characteristics. In the 1920s, the first American cinemas with air conditioners used slogans such as "Cool comfort" or "It's cool inside". The Carrier company presented its products with slogans like "No heat waves here!" or "Portable summer" in the same period. This approach progressed into the notion of creating one's own climate in the 1950s: "Heat and cool your home with a modern miracle - the Carrier heat pump Weathermaker!". The construction of such a mentality in relation to the properties of indoor climate stressed a different perception of the architectural space for both inhabitants and designers.

"If we want to keep the air in a room fresh and stimulating we must not let get it too warm, too moist, too still. We ventilate rooms for freshness and variety in the atmosphere, not for purity [...] Mr. Everyman's skin, it is the climate under his clothes that matters". The Science of Life (Wells, Huxley, and Wells, 1934, p. 1082).

The semantic shift from the air control to the notion of climate reflects the modern belief that artificial atmospheric qualities could help modern society to overcome the limitations of the natural environment (Pillon, 2007). Such change becomes more obvious if we take into account terms used in French (climatisation), in Spanish (climatización) or in German (Klimaanlage). The notion of climate, easily appropriable by experts and nonexperts, articulated knowledge of an array of fields (economy, techniques, physiology, geography or meteorology), different scales (territory, city or building) and different sources (natural and artificial). Hence, from the full air conditioning of the space in the 1920 s to the early beginnings of the "self-climate" construction in the 1950s, collaborations of a broad range of professionals explored the physiological, cultural and 
sensory aspects of thermal atmospheres in architecture. By revisiting the term of 'artificial climate', engineers and physiologists brought together the knowledge of climates and thermal control in order to create the indoor atmospheres of Modernism. Their proximity and influence in the modern architectural programme triggered collaborations, as in the case of Le Corbusier (L.C.), who collaborated with heating and ventilation engineers (Gustave Lyon and André Missenard) as well as with physicians (Winter and Carrel). The evolution of the architect's work from the late 1930s onwards, but in particular during the 1950s, is a paradigmatic case study of this kind of exchange.

\section{Thermal landscapes within: between neutrality and heterogeneity}

13 By the beginning of the 1910s, occupational doctors realised that longer working hours in enclosed spaces - i.e. factories or offices - with precarious environmental conditions affected workers' health and productivity. From 1911 onwards, doctor Leonard Hill from the London Hospital Medical College began a new research field on workplace ventilation and its physiological and psychological consequences (Hill and Campbell, 1925). In the 1920s, doctor Charles E.A. Winslow from the Yale Department of Public Health continued this line of research and extended his studies to students' efficiency in the classrooms. Similarly, doctor Louis Bargeron in France focused on environmental regulation:

"If the light is missing or, conversely, too intense, if the temperature is too low or too high, if the air is infected with sickly germs or deleterious vapours, the living body will soon react against the environment [...] A part of his energy will be mobilized for this struggle, and consequently, it will be lost for production: the efficiency of the human engine will diminish. If it happens that the external conditions are changed in the sense of improvement, the engine will increase its power accordingly [author's translation]" (Bargeron, 1922, p. 39)1.

Based on the hegemonic analogy of the body-machine, American and European researchers conducted in vitro experimental studies that considered participants as passive receptors of stimuli. They defined a set of ambient conditions that balanced environmental stimulation and neutralized sensory perception, which was defined as thermal comfort. Through the definition of new standards, like the Comfort Chart (1922) of the American Society of Heating and Ventilating Engineers (ASH\&VE), they established the socio-technical conditions for the propagation of sensory neutrality and indoor atmosphere homogenisation. In this regard, several authors (Heschong, 1979; Rahm, 2009; Moe, 2010) have stated that modern western architecture trivialized indoor climates, focusing heat transfers on thermal conduction and homogenising indoor temperature for all kinds of buildings.

Between the 1920s and the 1930s, Modern Architecture evidenced both the mechanistic thought and the hygienic background. In this period, L.C. presented his ventilation device, the "respiration exacte (correct breathing)" (Le Corbusier and Jeanneret, 1935). Studied by several authors (Gallo and Fernandez, 2014; Torres Cueco, 2004), it integrated into architecture the combination of the engineering ideas of Gustave Lyon's (1857-1936) "aération ponctuelle (spot ventilation)" for theatres and Raoul Decourt's "maison isotherme (isothermal house)" (1925). This proposal sought to establish a new architecture detached from outdoor climate, one which standardized indoor climates. In L.C.'s words: "to manufacture all year through the exact air, dusted off, disinfected, exactly 
humidified and heated to a constant temperature of about $18^{\circ}$ [author's translation]" (Le Corbusier 1933, 42)3. Projects like the Centrosoyuz (Moscow, 1928) or the Cité de Refuge (Paris, 1929) reflected this vision of thermal indoor atmospheres that already existed in the architect's manifesto "Vers une architecture" (Le Corbusier, 1923): "a house that is this human limit, surrounding us, separating us from the natural antagonist phenomenon, giving us our human milieu, to us human beings [author's translation]"4. As Torres Cueco (2014) argues, for L.C. this fully controlled house constituted a protective agent against a chaotic natural environment which hindered the development of human life.

This approach of climate neutralization in architecture circulated throughout Europe and America (Fitch 1948). For instance, in Chicago's World's Fair (1933-1934) - entitled Century of Progress - the exhibition "House of Tomorrow" presented a full air controlled prototype where air conditioning systems "automatically keep the air within buildings fresh, odourless, dustless and of a constant temperature and humidity at all times and all the seasons" (Century Homes, 1933, 2). A decade later, two experimental housing programmes promoted by large-circulation architecture magazines included thermal techniques in their construction of the American house atmosphere: Case Study Houses of Arts \& Architecture (1945-1953) and Pace Setter Houses of House Beautiful (1946-1965).

17 In parallel, a number of physicians and engineers stated that indoor ambiances were not intended to replace the natural climate; rather, they were supposed to create a parallel climate that operated similarly but just softening extreme conditions. In this regard, starting in the 1920s, a different spectrum of engineering and scientific contributions attempted to articulate natural and artificial climates. They tried to materialize indoor atmospheres that reproduced the climate's continual variability and its spatial heterogeneity to improve physiological and psychological efficiency. Various inventions constitute evidence of this alternative point of view: the patent for Vitaglass, permeable to UV rays (Sadar, 2008); the variable-speed fans and the air ionization systems (Cooper, 1998); the vaccination by medically processed air (Missenard, 1937).

Within this framework, the engineer Missenard established a new field that collated climatic studies with the emerging thermal control techniques: the "science des climats artificiels (science of artificial climates)" (Missenard, 1937). It brought together knowledge and processes that allowed the creation of indoor climatic conditions characterized by "the level of thermal sensation, the cleanliness of air, the level of auditory sensation, the content of ions, the pressure, etc. [author's translation]"5 (Goenaga, 1948).

Soon the scientific community echoed Missenard's proposal, as demonstrated by the appearance of artificial climates in the multidisciplinary committees of the League of Nations on housing or in the working parties of the Fondation Française pour l'Etude des Problèmes Humains (FFEPH). The architect community, furthermore, welcomed this new field of knowledge, inviting Missenard and some of his colleagues to write for journals like L'Architecture d'Aujourd'hui and L'Homme et l'architecture. The engineers' community also respected Missenard, for example he was appointed chairman of the scientific conferences of the Institut Technique du Batiment et des Travaux Publics in the post-war period. As a member of an intellectual and political elite, the engineer had contact with L.C., and together they explored the thermal qualities of Modern Architecture during the 1950s.

Missenard stated that although thermal conditioning techniques had developed rapidly during the early twentieth century, their consequences for human physiology had remained little studied. His works after 1937 paid special attention to showing an updated 
state of the art of scientific studies on the effects of exposing animals or human beings to climates for which they were not adapted. They highlighted topics such as extreme hot/ cold temperatures, high/low humidity, air ionization, or climate homogenization. Consequently, artificial climates, as Missenard conceived them, should not only create the ideal conditions in terms of air quality and temperature, but they also had to stimulate inhabitants to prevent physiological accommodation.

To do so, Missenard suggested some determining characteristics for indoor atmospheres. Firstly, he argued in favour of keeping inhabitants' living conditions close to those of their natural climate, which prompted the best physiological performance of their vital and social tasks. In his own words: "for the great majority of human beings acclimatised to their habitat, the most rational solution, although seemingly paradoxical, would be to change their natural climate as little as possible [author's translation]" (Missenard, 1934, p. 18) ${ }^{6}$. The engineer, hence, stood against the sensory neutrality disseminated by thermal comfort standards, which would have weakened the human immune system (Missenard, 1940; Missenard, 1946).

Secondly, Missenard aimed to strengthen inhabitants' thermo-regulation systems through a continuous and unconscious thermal training conducted by indoor atmospheres. He envisioned a holistic theory of strengthening health through temperature, like many others at that time - such as the nutritional control of John $\mathrm{H}$. Kellogg (1852-1943) or Alexis Carrel (1873-1944). As Vigarello (2006) explains in relation to sports, the programmatic training of bodies to attain their best was a common point of view at this time. For Missenard's thermo-regulation training, indoor atmospheres had to be heterogeneous across the building. On the one hand, indoor climate temperatures should be coupled with outdoor ones, with the aim of achieving a difference no greater than $7-8{ }^{\circ} \mathrm{C}$ and preventing temperatures that were too cold or too hot. Indoor atmospheres would have maintained the natural thermo-regulation training all day through, and it would have avoided high thermal contrasts. Thermal control through inbetween spaces became crucial to producing this adaptation. On the other hand, thermal conditions had to be adapted to the function of the space and the metabolic needs of inhabitants; therefore, each space would have different conditions and bodies would have been in a state of continuous reaction.

Other engineers were interested in this idea at the same time. Engineer Robert Leroux, lecturer in applied climatology at the Institut international d'urbanisme de Bruxelles, revisited the term climate in housing atmospheres. In 1946, he published the article "La climatologie de l'habitation", which established a method of "allowing us to determine the housing conditions depending on three types of geographical data [author's translation]" (Leroux, 1946) ${ }^{7}$. In 1950, he presented the method Leroux-Dell'Oro for the journal Techniques et architecture (Leroux, 1949), with the intention of integrating climate into architectural design.

\section{Le Corbusier: a modern awareness of climates}

Two main facts show the receptivity of L.C. to Missenard's science of artificial climates. On the one hand, he paid special attention to physical activity and contact with nature. The young Charles-Edouard Jeanneret was committed to the cold baths and daily exercises recommended by Jørgen P. Müller's method for health; hence, physical fitness and bodily exposure to climate had influenced him since childhood (Benton, 2014). 

climatic theory, entitled "Rétablir les conditions de nature" (1957). In this text L.C. stated, like Missenard, that the construction of artificial climates up to that point had interacted with human beings in uncontrolled ways. Science, according to him, had begun to reveal the effects of such detachment of bodies from their environment. Furthermore, L.C.'s text shows an emerging attention to the different meanings of climate as a part of the human milieu, which could be either natural or artificial. Closer to Winter's approach, he argued for developing a built environment that restored the richness of natural climates in the city.

"Nature had established, throughout the development of the species, a close interdependence between human beings and their environment, providing in this way a fertile game of reactions favourable to the maintenance of the human machine, of both muscle and nerve [...] A diversity was imposed, placing human beings in a permanent state of accommodation, defence, maintenance, strengthening [...]. The sedentary life, taking human beings away from their natural environment, depleting and delimiting dangerously their physical activities [...], their capacity to adapt to contrasting ambiances. A notoriously artificial 
environment was created, charged with nervous tension. The body - muscles and nerves - could have no satisfaction, leaving itself to drift, detached from natural conditions [author's translation]" (Le Corbusier, 1945, p. 63) ${ }^{10}$.

29 His collaboration with Missenard during the 1950s transformed his work in a laboratory for exploring the materialization of modern thermal atmospheres. In this regard, architecture as a way of creating artificial climates should guarantee heterogeneous and stimulating environments that interacted with the inhabitants. To do so, he theorized about "Rétablir les conditions de nature (restoring the conditions of nature)" based on five postulates already existing in the Ville Radieuse: the twenty-four-hour day, the sports at the doorstep, nature coming into the home, the green city, and the modern technologies being appropriate ${ }^{11}$.

In July 1961, L.C. gave a lecture at the Faculty of Medicine of Paris, entitled "Conditions of nature, effective and efficient urbanism". The conference explained the contrast between the natural rhythms of life, adaptive and variable, and the monotonous rhythms imposed in the machine age. In his own words: “... the alternation which is a phenomenon of human nature. All that is human alternates: walking, eyes flickering, talking, the lips that speak, whatever you want, I do not care, it is alternating whereas the machine, it is continuous [author's translation]"12.

31 Although L.C. and Missenard seemed to agree on their essential principles, they differed in their views of how to achieve them. The architect advocated a continuous immersion of inhabitants in the "conditions of nature", regardless of their natural or mechanical method of manufacture: both outdoor and indoor environments should place inhabitants in such natural conditions once more. As he said in the article "Aux approches d'une synthèse", architecture would contribute to restoring the "conditions of nature". Meanwhile, Missenard thought that artificial climates should not replace or imitate the real immersion in nature. Atmospheres inside buildings should create the optimal conditions for health and productivity, yet they should not give the impression of being outdoors. Moreover, in a more radical assertion, Missenard explained that they could prompt inhabitants to go outdoors once their indoor tasks were finished. Consequently, the architect seemed to be closer to Winter's approach: architecture should create living climates that mediate between indoor and outdoor climates through architectural strategies and devices.

“... it is at least cautious to expose adults as much as possible, and children in particular, to natural climates. We must force them to live outside as often as possible [...]it is worrying that the large bays of Le Corbusier, 'incorporating landscape in housing', give the dangerous illusion of an open-air life [author's translation]" (Missenard, 1954, p. 240) ${ }^{13}$.

\section{Architecture as a mediator between climates: the Grille Climatique}

The earliest attempt at bringing together Missenard's and L.C.'s ideas was the generation of a climate-inclusive design method, the "Grille Climatique (climatic grid)". After coming back from Chandigarh in November 1951, L.C. wrote to Missenard asking for his advice about the challenge that this commission in a different climate entailed for him. The letter showed his intention of developing a method of generating works that could operate in any particular set of climatic conditions. Besides, the architect revealed his 
wider aim: to investigate experimental procedures for regulating thermal atmospheres through architecture. In L.C.'s words: "the regulations concerning this new capital imply decision-making in terms of hygiene laws (of a quite different nature than our conformist regulations that had resulted from all the agreements) [author's translation]" ${ }^{14}$.

A second letter from L.C. dated $6^{\text {th }}$ December ${ }^{15}$ detailed the collaboration process actually it seems rather to be a consultancy protocol. He suggested that the architect would send his ideas to Missenard by letter, then he should answer with an affirmative or negative response, or even with a modification sketch. Depending on the results of this analysis, L.C. continued, they would figure out how to continue this experience afterwards. On $12^{\text {th }}$ December ${ }^{16}$, Missenard answered enthusiastically, calling for greater involvement of his company and himself - a request that L.C. never answered.

On $16^{\text {th }}$ December, the "Study programme of optimal climatic conditions and architectural means of correction" 17 was established by Iannis Xenakis (1922-2001), a Greek-French engineer, architect and composer who worked with Le Corbusier. Xenakis specified four variables for the "climatic ambiance (air temperature, relative humidity, direction/velocity of winds and thermal radiation)" in order to determine "the optimal and theoretical variations of the ambiance to conserve or to increase the best VITAL efficiency [author's translation]"18. As Siret (2005) argues, this programme put together ideas relating to climate and physiology in a precise manner that seems to be clearly directed by Missenard.

After that, on $21^{\text {st }}$ December ${ }^{19}$, the Colombian architect German Samper (1924), a L.C.'s assistant, drew up the "General outline for the grid for the climatic conditioning of the Secretariat", which could be understood as an early test of the grid criteria for the Secrétariat building. He took into consideration six climatic factors instead of the previous four: sun, light, air temperature, prevailing winds, rainfall and relative humidity. The chart was divided into three columns that would define the stages of the method: climatic data, optimal conditions to be reached and architectural procedures. On the same date, L.C. informed Jane Drew (1911-1996) that the "grid of climatic hygiene"20 had been established with the aid of Missenard. The evolution of the title and the headers of the grid throughout the process provide evidence of the engineer's influence (Requena-Ruiz and Siret, 2014).

Missenard's last intervention appears to have been on $16^{\text {th }}$ January $1952^{21}$ during a meeting with L.C. and his collaborators. The chart entitled "Desirable correction in the spaces (A. Missenard)" collected the engineer's suggestions for achieving optimal indoor conditions in the project of "Maison des Péons $110 \mathrm{~m}^{2}$ " in Chandigarh. The columns were divided into twelve months, whereas the rows restored the four comfort parameters previously mentioned. Comments were explained in terms of quantitative notes for temperature, air velocity and humidity, whereas corrections in thermal radiation were suggested as a qualitative aspect.

The final chart was drawn up in a document dated $31^{\text {st }}$ January, being finally named Grille Climatique ${ }^{22}$. In Xenakis's text it was defined as "a graphical means of presentation which permits the enumeration, coordination and analysis of the climatic conditions of a place (defined by its latitude) in order to direct architectural research towards solutions in accord with human biology" 23 . Thus, they declared their intentions regarding indoor atmospheres: "it deals with the rectification and setting in order of the excesses of extreme climates in order to achieve, by means of architectural dispositions, conditions capable of assuring comfort and well-being"24. 
phases' approach explained in although the titles changed in a subsequent version. The first, "ambient conditions" (later "climatic data") preserved Missenard's four factors for effective temperature. The second column was entitled "corrections from the standpoint of comfort and well-being" (later "correction proposals"), which replaced that of "optimal conditions" and the search for the "best vital efficiency". As it is explained, the information here should be provided by a "physical biologist", establishing the real programme that calls for the architect's intervention (Siret, 2005). In this case, the criteria were based on Missenard's document of $16^{\text {th }}$ January. The third column, called "architectural solutions" (later "architectural processes"), signalled by a stamp with the letter D and a numeric code the existence of an architectural strategy. A set of sixteen explanatory drawings signed by L.C., constituted a catalogue of environmental solutions to be applied by architects.

The chart influenced other documents at the same time. For instance, the climatic section of the Secretariat (FLC 2827) explains the interaction of architecture with sun, light, rain and wind. Similarly, the drawing of the High Court's natural ventilation (FLC 4639) was based on the Grille Climatique strategies. The topic was also duly studied for the Villa Sarabhai (FLC 6676). In general terms, the plans for the Indian projects included, almost systematically together with the North arrow, a scheme with summer and winter solar angles as well as the direction of the prevailing winds for each season (Requena-Ruiz, 2012).

After this prolific period, the Grille Climatique disappeared from the works of the atelier. However, during the Chandigarh building works in May 1956, L.C. sent to the Indian government a letter that highlighted the importance of controlling indoor thermal conditions. He once again supported the design method: "but this Climatic Grid has not been taken into account in Chandigarh and I regret it bitterly [...] this grid has been lost, I am ready to draft a new one if I am asked [author's translation]"25.

41 This document allows the Grille Climatique and L.C.'s approach to indoor thermal atmospheres to be put into perspective. If study of the Grille Climatique could indicate that L.C. advocated using natural resources - subsequently called bioclimatism - the text shows a different point of view. In his opinion, architecture must guarantee users' health and comfort through the control of lighting level, ventilation and temperature. To achieve this purpose, he suggested that several techniques could be applied, depending on the budget: air conditioning, fan ventilation or natural cross-ventilation.

"It involves the supply of pure air to the lungs. In cold countries, it involves the heating of this air; in hot countries the cooling of this air (air conditioning). If the funds are insufficient, replace the air conditioning with the effects of the air stream triggered by the arrangement of openings and the wind (cross-ventilation). If there is no wind, apply artificial wind (fan). If ambient air is warmer than the human body, apply the fan as a last resort, as the only economical method (when air conditioning cannot be applied) [author's translation]"26.

Study of subsequent projects without the support of Missenard, such as the Olivetti Calculation Centre (1963), the Tokyo Western Art Museum (1957-59) or the Hospital of Venice (1964), reveals that L.C. did not reject mechanical air control. Rather, passive methods and air conditioning became part of the whole range of strategies to achieve healthy and stimulating indoor atmospheres. 


\section{Artificial climates in action: radiant systems and Modernism}

43 Although the Grille Climatique was a remarkable example of this collaboration, study of the files of the FLC shows that it was an exceptional case. The interaction between L.C. and Missenard after the Grille Climatique was mostly limited to a routine of courtesy correspondence: new publications, the main changes in their companies, greeting cards or congratulatory letters about new buildings ${ }^{27}$. However, the end of this early project was the beginning of an intensive cycle of exchange at a professional level, which mainly took place between their architectural and engineering firms' partners.

During this period, Missenard was head of the company Ets Missenard-Quint that specialized in central heating systems. The company, as their communication policy reveals, set itself apart from its competitors ${ }^{28}$ via its climate design approach. For instance, their advertisement in 1935 in L'Architecture d'Aujourd'hui highlighted their skill in creating optimal health and comfort conditions for indoor atmospheres ${ }^{29}$. It was also the case with their commercial leaflets of the 1950s, the cover of which bore the text "New techniques in Artificial Climates. Ets Missenard-Quint"30.

Like other engineers of his time, Missenard trusted that modern radiant systems (heating/cooling) satisfied the requirements for healthy atmospheres, which in his case mostly reflected the ideas behind the science of artificial climates. As previously mentioned, his criteria for indoor atmospheres were to modify the natural thermal conditions as little as possible, to vary temperatures throughout the day like the outdoors, and to create a spatial heterogeneity according to the inhabitant's activities and movements.

Missenard argued for thermal radiation advantages in indoor atmospheres for several reasons: the low heating temperature that minimized air conduction currents, which were believed to foster the spread of germs deposited on surfaces; the freedom with regard to interior partitions; the possibility of keeping cooler air temperatures, which was apparently healthier for the lungs; the system's durability, given that it would have been embedded in the concrete slabs. The engineer, paradoxically, distrusted a widespread theory that compared the properties of radiant systems to the natural heat radiation received from the sun (ceiling heating) or from the ground (floor heating). Even if he accepted that radiating heat transfer was more akin to the natural method, he did not agree with the idea of bringing artificial heating systems and the properties of real sunlight to the same level (Missenard, 1937).

In the 1940s, Missenard developed his own radiant heating system patent, the "Système Missenard". It was composed of medium-diameter ducts that were embedded in the concrete slabs, adding the heating function to the structural element. In addition to his patent, Ets Missenard-Quint also exploited in France the radiant surfaces system of Richard Crittall \& Co. The British company's system focused on small-diameter ducts installed inside the finishing layer of ceilings and walls. Such a method was also adopted by modern architects such as Alvar Aalto and Johannes Duiker. The relationship between both innovative companies and their systems and outstanding modern architects is evidence of the interest in modern ambient control techniques and their integration in architecture. 
Given that the radiant heating systems were designed to perform efficiently following the principles of high thermal inertia and constant temperature, Missenard had to adapt them to match up with the climate-responsive logic of the science of artificial climates. To do so, the Ets Missenard-Quint developed several strategies that we can find in the technical reports of their projects with the Atelier L.C.

Firstly, they differentiated the main heating circuits according to their balance of losses and gains. In the case of the Unité d'Habitation of Rezé, for instance, the system had six dedicated heating circuits that brought together spaces with similar functionality and exposure: façades - east, west, north, south - first floor and last floor. Secondly, the temperature of the carrier fluid was continuously regulated by a couple of thermal sensors - indoor and outdoor - for each circuit. The Ets Missenard-Quint developed this technology to allow adaptation to external temperature variations. Indoor temperature, however, was automatically controlled according to the engineers' criteria and did not allow interaction on the part of the inhabitants. Thirdly, the temperature of each group of spaces was conceived according to its function and its situation in the daily journey of the inhabitants. As evidenced by the installations of the Maison du Brésil (1959), the indoor-outdoor thermal lag was mitigated by a transition from the rooms heated up to $18^{\circ} \mathrm{C}$, passing to the unheated corridors, crossing the ground floor heated up to $15^{\circ} \mathrm{C}$ and leaving the building through a glazed transition chamber. Finally, they also juxtaposed multiple heating systems to facilitate more accurate thermal regulation: a general heated floor system to ensure a basic minimum temperature; convector heaters for the most exposed ground floor, first floor and last floor spaces; and an air conditioning system for the theatre.

As with the façade and the "mur neutralisant (neutralizing wall)" in the 1920s, the floor became essential for L.C.'s architecture in the 1950s. Beyond its constructive meaning, it brought together tectonics, thermics and aesthetics, which is to say both physical and sensory dimensions in architecture. The Maison du Brésil or the several Unités d'Habitation after Marseilles were examples of this. Housing floors were finished with linoleum flooring according to the Dalami patent, in tiles measuring $30 \times 30 \times 1 \mathrm{~cm}$. The choice of material enhanced its surface finish qualities - modern aspect, continuity, cleanliness - as well as its heat transfer properties and its resistance to swelling. The ground floors had a more public character. In the Maison du Brésil it was finished with parallel strips of black slate sheets of different widths, whereas for the Unités d'Habitation the architect reproduced the same pattern in a cement-based finish. Sunlight and lighting reflections, as well as its natural freshness and warmth when heated, create an enveloping experience in thermal and visual terms. As previously mentioned, the heating floor system simplified the materialization of the ground floor's spatial characteristics - spatial continuity, variable clearance height and curved walls.

51 In short, the example of the floor heating system reveals, on the one hand, that the collaboration of Missenard and L.C. explored a richer and more complex interaction of architecture, inner climates and inhabitants' bodies. On the other hand, it also shows an embodied approach of the architectural space through the overlapping of the environmental control systems with the spatial and sensory perception of the inhabitants. 


\section{Conclusion}

52 reveals that it was not the only approach. Rather, this article explains how several professionals and researchers sought to coordinate artificial and natural climates instead of opposing them. The various examples, including the works of L.C. and Missenard, reveal the intention to promote a closer relation between inhabitants and the outdoor climate; fully controlled conditions were therefore limited to peak periods. In addition, control of other aspects such as air humidity, air movement or air quality, as well as the projects for air ionization or vaccination, suggest that they aspired to improve outdoor conditions inside the buildings rather than to replace them. In other words, they aimed to create "augmented climates" that contributed to the construction of the Homme Nouveau's society.

The exchanges between L.C. and Missenard, in addition to their collaborative work, are a useful case study for understanding the materialization of such an intangible subject. We have seen how L.C.'s manifestos in the late 1950s and early 1960s expressed his interest in thermal and climatic conditions in architecture, as well as their relationship with outdoor climate and their influence on inhabitants' bodies. The architect's approach was based on the ideas of Dr. Winter - body training and contact with nature - and the engineer Missenard - thermoregulatory system training and artificial climates. In-depth study of their professional collaboration during the 1950s reveals the progressively more complex interrelatedness of the material shapes of architecture and the intangible effects of artificial climates. In this regard, both architect and engineer took a flexible and openminded approach to the method for creating artificial climates. They could be created 
either by modifying the natural climate through passive strategies or by using mechanical devices. However, it seems impossible to isolate the material translation of artificial climates in L.C.'s architecture, although it is clear that matter and spatiality were intimately related to the use of those particular techniques. What is more, the several dimensions of indoor atmospheres, which were brought together by the science of artificial climates, appear nowadays as a relevant entry point for the study of thermal perception in architecture.

Le Corbusier. 1966 [1923]. Vers une architecture. Paris : Vincent et Fréal

The author would like to thank the Fondation Le Corbusier and the Bibliothèque Nationale de France for access to their documentary resources. This research has been supported by the Fondation Le Corbusier - Bourses pour Jeunes Chercheurs 2013.

\section{BIBLIOGRAPHY}

Ackermann, Marsha E. 2002. Cool Comfort: America's Romance with Air-Conditioning. Washington: Smithsonian Institution Press.

Anker, Peder. 2010. From Bauhaus to Ecohouse. A History of Ecological Design. Louisiana: Lousiana State University Press.

Banham, Reyner. 1969. The Architecture of the Well-Tempered Environment. London: The Architectural Press.

Barber, Daniel. 2010. The Solar House Principle. Architectural Experimentation and Infrastructural Engagement. $\mathrm{DASH}, \mathrm{n}^{\circ} \mathrm{7}, \mathrm{p} .18-33$.

Bargeron, Louis. 1922. Influence des facteurs physiques sur le rendement du moteur humain. Annales d'Hygiène Publique, janvier-décembre, p. 39.

Barlow, Kenneth. 2012. The Peckham Experiment. Medical History, vol. 29, n³, p. 264-271.

Benton, Tim. 2014. Le Corbusier et le sport. In: Mandoul, Thierry (ed.). Sports. Portrait d'une métropole. Paris: Editions du Pavillon de l'Arsenal. p. 190-195.

Böhme, Gernot. 1993. Atmosphere as the Fundamental Concept of a New Aesthetics. Thesis Eleven, vol. $36, \mathrm{n}^{\circ} 1$, pp. 113-126.

Campbell, Margaret. 2005. What Tuberculosis Did for Modernism: The Influence of a Curative Environment on Modernist Design and Architecture. Medical History, vol. 49, n 4, p. 463-488.

Carrier, Willis H. \& Busey, Frank L. 1911. Air-Conditioning Apparatus; Principles Governing Its Application and Operation. In: ASME Transactions, New York, 1911. p. 1055-1136.

Carter, Simon. 2007. Rise and Shine. Sunlight, Technology and Health. Oxford: Berg.

Carter, Simon. 2012. The Medicalization of Sunlight in the Early Twentieth Century. Journal of Historical Sociology, vol. 25, $\mathrm{n}^{\circ} 1$, p. 83-105.

Century Homes. 1933. House of Tomorrow [Exhibition. Chicago World's Fair]. Chicago: Neo-Gravure co. 
Chang, Jiat-Hwee \& Winter, Tim. 2015. Thermal Modernity and Architecture. The Journal of Architecture, vol. 20, n¹, p. 92-121.

Chappells, Heather \& Shove, Elizabeth. 2004. Comfort: A Review of Philosophies and Paradigms. Lancaster: University of Lancaster ; UK Economic and Social Research Council's EHB. Research Report.

Châtelet, Anne-Marie. 2011. Le souffle du plein air : Histoire d'un projet pédagogique et architectural novateur (1904-1952). Genève: MetisPresses.

Cogdell, Christina. 2004. Eugenic Design: Streamlining America in the 1930s. Philadelphia: University of Pennsylvania Press.

Colomina, Beatriz. 1994. Privacy and Publicity: Modern Architecture as Mass Media. Cambridge: The MIT Press.

Cooper, Gail. 1998. Air-Conditioning America: Engineers and the Controlled Environment, 1900-1960. Baltimore: John Hopkins University Press.

Corbin, Alain. 2008 [1982]. Le miasme et la jonquille. Paris: Flammarion.

Farish, Matthew. 2013. Creating Cold War Climates. The Laboratoires of American Globalism. In: McNeill, J.R. \& Unger, C.R. Environmental Histories of the Cold War. New York: Cambridge University Press. p. 51-85.

Fernandez-Galiano, Luis. 2000. Fire and Memory: On Architecture and Energy. Cambridge: MIT Press. Fitch, James M. 1948. American Building. The Forces That Shape It. Boston: The Riverside Press, Cambridge.

Fleming, James Rodger \& Jankovic, Vladimir. 2011. Revisiting Klima. Osiris, vol. 26, n¹, p. 1-16. Foucault, Michel. 1990 [1966]. Les mots et les choses: Une archéologie des sciences humaines. Paris: Gallimard.

Foucault, Michel. 2004. Naissance de la biopolitique. Cours au Collège de France. 1978-1979. Paris: Seuil, Gallimard.

Gallo, Emmanuelle. 2008. Modern Movement Architecture and Heating Innovations in France 1900-1939. In: Tomlow, Jos \& Wederbrunn, Ola (eds.) Docomomo Technology Seminar. Climate and Building Physics in the Modern Movement. Löbau: DOCOMOMO. p. 91-96.

Gallo, Emmanuelle \& Fernandez, Vanessa. 2014. The Glass Façade and the Heating System of the Salvation Army City of Refuge. Docomomo Preservation technology Dossier, vol. 13, p. 45-55 Goenaga, R. 1948. Conditionnement de l'air. Ses applications dans l'habitat et dans l'industrie. Annales de l'Institut Technique du Bâtiment et des Travaux Publics, vol. 37, p. 4-11.

Heschong, Lisa. 1979. Thermal Delight in Architecture. Cambridge: MIT Press.

Hill, Leonard \& Campbell, A. 1925. Health and Environment. London: Edward Arnold \& Co.

Hobday, Richard. 2006. The Light Revolution: Health, Architecture, and the Sun. Forres: Findhorn Press.

Hulme, Mike. 2011. Reducing the Future to Climate: A Story of Climate Determinism and Reductionism. Osiris, vol. 26, n¹, p. 245-266.

Ingold, Tim. 2000. The Perception of the Environment: Essays on Livehood, Dwelling and Skill. London: Routledge. 
Jankovic, Vladimir. 2010. Confronting the Climate: British Airs and the Making of Environmental Medicine. New York: Palgrave Macmillan.

Le Corbusier. 1964 [1935]. La ville radieuse : eléments d'une doctrine d'urbanisme pour l'équipement de la civilisation machiniste. Paris : Vincent et Fréal.

Le Corbusier. 1959 [1945]. Les Trois établissements Humains. Paris : Les Editions de Minuit.

Le Corbusier. 1957. Rétablir les conditions de nature. Espaces Verts et Jardins, vol. 7, p. 33-43.

Le Corbusier; Jeanneret, Pierre. 1974 [1935]. Le Corbusier et Pierre Jeanneret. Oeuvre Complète 1929-1934. Basel : Birkhäuser.

Leroux, Robert. 1946. La climatologie de l'habitation. Annales de l'Institut Technique du bâtiment et des Travaux Publics vol. 7, p. 96-107.

Leroux, Robert. 1949. Essai sur une nouvelle climatologie de l'habitation en France. Techniques et Architecture, vols. 7-8, p. 35-43.

Loudon, John C. 1817. Remarks on the Construction of Hothouses. London: J. Taylor.

Marino, Giulia. 2014. “Some Like It Hot!” Le confort physiologique et ses dispositifs dans l'architecture du $X X^{e}$ siècle: Histoire et devenir d'un enjeu majeur. PhD Thesis. Lausanne: Ecole Polytechnique Fédérale de Lausanne.

Missenard, André. 1934. Le conditionnement des locaux. Conceptions et réalisations modernes. La Technique Moderne, vol. 26, n7. n.p.

Missenard, André. 1937. L'Homme et le climat. Paris: Librairie Plon.

Missenard, André. 1940. A la recherche du temps et du rythme. Paris: Plon.

Missenard, André. 1946. La chaleur animale. Paris: Presses Universitaires de France.

Missenard, André. 1954. A la recherche de l'homme. Paris: Librairie Istra.

Moe, Kiel. 2010. Thermally Active Surfaces in Architecture. New York: Princeton Architectural Press.

Ory, Pascal. 2006. Le corps ordinaire. In: Corbin, Alain; Courtine, Jean-Jacques; Vigarello, Georges. Histoire du corps (vol. 3). Les mutations du regard. Le XX siècle. Paris: Editions du Seuil. p.129-162.

Ory, Pascal. 2008. L'invention du bronzage : Essai d'une histoire culturelle. Paris: Editions Complexe.

Overy, Paul. 2007. Light, Air \& Openness: Modern Architecture between the Wars. London: Thames \& Hudson.

Pallasmaa, Juhani. 2011. Space, Place and Atmosphere: Peripheral Perception in Architectural Experience. Arkkitehti, vol. 5, p. 14-25.

Pillon, Thierry. 2007. Le corps et l'air artificiel. Communications, vol. 81, n¹, p. 85-100.

Rahm, Philippe. 2009. Architecture Météorologique. Paris: Archibooks.

Requena-Ruiz, Ignacio. 2012. Medio ambiente y modernidad en la obra de Le Corbusier a través del dibujo. Expresión Gráfica Arquitectónica, vol. 20, p. 246-255.

Requena-Ruiz, I., Siret, D., 2014. Experiments on Thermal Comfort and Modern Architecture: The Contributions of André Missenard and Le Corbusier. In: Rosso, Michela (ed.). EAHN Third International Meeting, Torino, 19-21 June 2014. Torino: Politecnico di Torino. p. 651-662.

Richards, Thomas. 1993. The Imperial Archive: Knowledge and the Fantasy of Empire. London \& New York: Verso. 
Sadar, John. 2008. The Healthful Ambience of Vitaglass: Light, Glass and the Curative Environment. Architectural Research Quaterly, vol. 12, n³-4, p. 269-281.

Simonnet, Cyrille. 2014. Brève Histoire de l'air. Versailles: Editions Quæ.

Siret, Daniel. 2005. Grille Climatique, 1951. In: Le Corbusier Plans (vol. 11). Paris: Echelle-1 \& Fondation Le Corbusier.

Siret, Daniel. 2013. Rayonnement solaire et environnement urbain: de l'héliotropisme au désenchantement, histoire et enjeux d'une rélation complexe. Revue Développement et Territoires, vol. 4, n². Disponible sur : http://developpementdurable.revues.org/9767 (consulté le 7 septembre 2016).

Sloterdijk, Peter. 2006. Esferas III - Espumas, Esferología Plural. Madrid: Ediciones Siruela.

Thibaud, Jean-Paul. 2014. Installing an Atmosphere. In: Böhme, Gernot; Griffero, Tonino \& Thibaud, Jean-Paul (eds.) Architecture and Atmosphere. Espoo: Tapio Wirkkala-Rut Bryk Foundation. p. 48-65.

Torres Cueco, Jorge. 2004. Le Corbusier: Visiones de la técnica en cinco tiempos. Barcelona: Fundación Caja de Arquitectos.

Torres Cueco, Jorge. 2014. Pensar la arquitectura: Mise au point de Le Corbusier. Madrid: Abada Editores.

Turda, Marius. 2010. Modernism and Eugenics. Hampshire: Palgrave Macmillan.

van der Plaat, Deborah. 2014. Architecture of Sun and Soil. European Architecture in Tropical Australia. In: Rosso, Michela (ed.). EAHN Third International Meeting, Torino, 19-21 June 2014. Torino: Politecnico di Torino. p. 1119-1130.

Vigarello, Georges. 2006. S'entraîner. In: Corbin, Alain; Courtine, Jean-Jacques; Vigarello, Georges. Histoire du corps (vol. 3). Les mutations du regard. Le XX ${ }^{e}$ siècle. Paris: Editions du Seuil. p. 169-206.

Wells, H.G.; Huxley, Julian \& Wells, G.P.1934. The Science of Life. New York: Cassels.

\section{NOTES}

1. Original quotation: "Si la lumière manque ou est, au contraire, trop intense, si la température est trop basse ou trop élevée, si l'air est souillé de germes morbides ou de vapeurs délétères, le corps vivant ne tardera pas à réagir contre le milieu [...] Une partie de son énergie se trouvera mobilisée pour cette lutte, et par suite, elle sera perdue pour la production : le rendement du moteur humain diminuera. S’il arrive que les conditions extérieures soient modifiées dans le sens de l'amélioration, le moteur accroîtra parallèlement sa puissance" (Bargeron, 1922, p. 39).

2. First published in a report of the New York State Commission on Ventilation in 1922 (Cooper 1998, p. 71).

3. Original quotation: “fabriquer toute l'année de l'air exact, dépoussiéré, désinfecté, exactement humidifié et porté à température constante de $18^{\circ}$ environ" (Le Corbusier 1935, p. 42)

4. Original quotation: "une maison qui soit cette limite humaine, nous entourant, nous séparant du phénomène naturel antagoniste, nous donnant notre milieu humain, à nous hommes" (Le Corbusier, 1923)

5. Original quotation: "le niveau de la sensation thermique, la pureté de l'air, le niveau de la sensation sonore, la teneur en ions, la pression, etc" (Goenaga, 1948). 
6. Original quotation: "pour la grande majorité des hommes acclimatés à leur habitat, la solution la plus rationnelle, quoique apparemment paradoxale, serait probablement de modifier le moins possible le climat naturel" (Missenard, 1934, p. 18)

7. Original quotation: "permettant de déterminer les conditions de l'habitation en fonction des trois données géographiques" (Leroux, 1946)

8. Original quotation: "réduire les maladies au strict minimum, construire des corps robustes et harmonieux sans des logis sains, sans des loisirs organisés, sans la reconstruction d'ateliers, de bureaux, sans la création de tout l'équipement Santé"

9. Original quotation: "Dans les villes actuelles, la lumière est malade : diminution des rayons U.V. (inefficacité de l'héliothérapie urbaine) diminution des infra-rouges (calorifiques) et perte des autres éléments vitalisants [...] le pan de verre, dans la ville polluée, est ce que nous pouvons souhaiter de meilleur; dans les villes à air pur, on ménagera toutes facilités pour le contact direct entre peau et lumière".

10. Original quotation: "La nature avait instauré, au cours du développement de l'espèce, une interdépendance intime entre l'homme et son milieu, assurant ainsi un jeu fertile de réactions favorables à l'entretien de la machine humaine, musculairement et nerveusement [...] Une diversité était imposée, mettant l'homme en état permanent d'accommodement, de défense, d'entretien, de renforcement [...] la vie sédentaire, éloignant les êtres de leur milieu naturel, appauvrissant et limitant dangereusement leurs activités corporelles [...] leur capacité d'adaptation aux contrastes de l'ambiance. Un milieu notoirement artificiel fut créé, chargé de tension nerveuse. Le corps -muscles et nerfs- n'y trouvait plus son compte, s'en allant à la dérive, détaché des conditions nature"

11. Original terms: les 24 heures solaires, le sport au pied des maisons, la nature est entrée dans le bail, la ville verte and les techniques modernes s'y prêtent.

12. Cf. Le Corbusier, "Conditions de nature, urbanisme efficace et efficient", Lecture at the Faculté de médicine in Paris, July 1961, FLC C3.10.46. Original quotation: "l'alternance qui est un phénomène de nature humaine. Tout ce qui est humain est alternatif : la marche, le battement des yeux, la parole, les lèvres qui parlent, tout ce que vous voudrez, ça m'est égal, c'est alternatif alors que la machine, elle, est continue"

13. Original quotation: “... est-il, pour le moins prudent, d'exposer le plus possible les adultes, et plus encore les enfants, aux climats naturels. Il faut les contraindre à vivre dehors le plus souvent possible [...] les grandes baies de Le Corbusier, 'intégrant le paysage dans le foyer' donnent la dangereuse illusion de la vie en plein air et, qu'ainsi, un bien devienne un mal par ignorance"

14. Le Corbusier, letter to André Missenard, 3 December 1951, FLC E2.16.14. Original quotation: "des règlementations concernant cette nouvelle capitale impliquent des décisions à prendre concernant les lois de l'hygiène (de tout autre nature que nos règlementations conformistes et fruits de tous les compromis)"

15. Le Corbusier, letter to André Missenard, 6 December 1951, FLC E2.16.15.

16. A. Missenard, letter to Le Corbusier, 12 December 1951, FLC E2.16.16.

17. I. Xenakis, "Programme d'études des Conditions Climatiques Optima et des Moyens Architecturaux de correction", 16 December 1951, FLC P2.1.1

18. Ibid. Original quotation: "les variations optima et théoriques de l'ambiance pour conserver ou accroître le meilleur rendement VITAL"

19. G. Samper - Atelier Le Corbusier, "Esquisse générale de la grille pour le conditionnement climatique du Secrétariat", 21 December 1951, FLC 2642.

20. Le Corbusier, letter to J. Drew, 21 December 1951, FLC P2.1.9.

21. A. Missenard, "Réunion Grille Climatique", 16 January 1952, FLC P2.1.27.

22. Atelier Le Corbusier, 31 January 1952, FLC P2.1.3. 
23. Original quotation: "un moyen matériel de visualisation permettant d'énumérer, de coordonner et d'analyser les données climatiques d'un lieu défini (par sa latitude) afin d'orienter la recherche architecturale vers des solutions accordées à la biologie humaine"

24. Original quotation: "il s'agit de régulariser et de rectifier utilement les débordements de climats excessifs et de réaliser par des dispositifs architecturaux les conditions capables d'assurer le bien être et le confort".

25. Le Corbusier, letter to Varma, 22 May 1956, FLC, P1.10.301, p.3. Original quotation: "mais cette Grille Climatique n'a pas été prise en considération à Chandigarh et je le regrette amèrement [...] cette Grille ayant été perdue je suis prêt à en faire établir une nouvelle et à l'envoyer à Chandigarh si on me la demande"

26. Le Corbusier, ibidem, p.2. Original quotation: "Elle comporte l'arrivée dans les poumons d'un air pur. Elle comporte dans les pays froids le chauffage de cet air; dans les pays chauds le refroidissement de cet air (air conditionné). Si les crédits sont insuffisants, remplacement de l'air conditionné par les effets du courant d'air provoqué par des dispositions, des ouvertures et l'aide du vent (cross ventilation). En cas d'absence du vent, application du vent artificiel (ventilateur, fan). En cas de chaleur de l'air ambiant plus élevée que celle du corps humain, application du ventilateur (fan) comme pis-aller et seule méthode économique (quand l'air conditionné ne peut pas être appliqué)".

27. At the FLC archive there are 26 letters between Le Corbusier and Missenard: 10 about the Grille Climatique, 5 about their new books and 4 on changes in the companies.

28. The French market was full of companies for heating and ventilating systems at that time. For instance: Gandillot (radiant floor heating system), Ets Mortreux (air convectors), Sulzer (central heating systems), Ets Neu (air conditioning) or Ateliers Ventil (ventilation).

29. L'Architecture d'Aujourd'hui, 1935, special number on "Chauffage et ventilation", p. 41.

30. Ets Missenard-Quint commercial leaflet, 1957, "Nouvelles techniques des climats artificiels", FLC, Q1.15.259.

\section{ABSTRACTS}

In the mid-twentieth century, the evolution of the various dimensions involved in the notion of climate led to a different vision of the relationship between bodies and indoor atmospheres. This article states that Modern Architecture hosted and promoted this change in cultural representations, social practices and technical developments of temperature and climate in indoor spaces. Our aim is to bring together points of view and interpretations of the cultural history, the history of techniques and the history of sensory perception in order to understand how the climatic dimension of indoor atmospheres became an agent of architectural transformation. In particular, the article focuses like a case study on the collaboration between Le Corbusier and André Missenard, a climate control specialist, through original archival research. As a result, we show how their theoretical reflections and built works illustrate a broader interest in architecture as a way of creating the ideal climates for modern ways of life.

$\mathrm{Au}$ milieu du vingtième siècle, l'évolution des questionnements autour de la notion de climat a entraîné un changement de regard sur la relation entre le corps humain et les ambiances architecturales. Dans ce contexte, nous avançons l'idée selon laquelle l'architecture moderne a accompagné et façonné la transformation des représentations culturelles, des pratiques sociales 
et des progrès techniques liés à la température et aux climats intérieurs. Pour ce faire, la méthode de recherche mise en œuvre interroge l'architecture moderne au prisme de l'histoire culturelle, de l'histoire des techniques et de l'histoire des sensibilités. Plus concrètement, nous prenons appui sur une recherche d'archives concernant la collaboration entre Le Corbusier et André Missenard, spécialiste en génie climatique. Cet article montre comment leurs réflexions théoriques et leurs réalisations construites sont représentatives d'un plus large intérêt sur l'architecture comme moyen de création de conditions climatiques idéales pour un mode de vie moderne.

INDEX

Mots-clés: climats artificiels, ambiances thermiques, architecture moderne, histoire des techniques, histoire culturelle, André Missenard, Le Corbusier

Keywords: artificial climates, thermal atmospheres, modern architecture, history of techniques, cultural history, André Missenard, Le Corbusier

\section{AUTHOR}

\section{IGNACIO REQUENA-RUIZ}

Ignacio Requena-Ruiz is a PhD architect by training and an Associate Professor at ENSA Nantes, where he conducts research at UMR CNRS Ambiances Architectures Urbanités - CRENAU. He has been a researcher at the University of Alicante (2011-2012) and postdoctoral fellow at the CERMA laboratory (2013-2014). He has been awarded a research fellowship by the Fondation Le Corbusier (2013).

Contact: ignacio.requena@crenau.archi.fr 